\title{
Properties advanced of the silicon nitride based ceramics and recent performance on automotive parts manufacture by machining process: Advanced Ceramics, demand Forecast
}

\author{
José Vitor Candido de Souza \\ Instituto Nacional de Pesquisas Espaciais - INPE/CTE/LAS \\ Maria do Carmo de Andrade Nono \\ Sergio Luiz Mineiro \\ Instituto Nacional de Pesquisas Espaciais - INPE/CTE/LAS
}

Olivério Moreira de Macedo Silva AMR-CTA

Marcos Valério Ribeiro UNESP-FEG

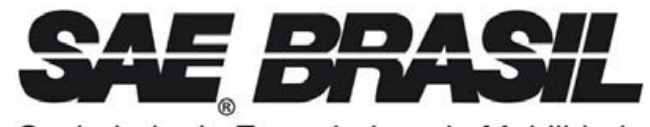

Sociedade de Engenheiros da Mobilidade FILIADA À

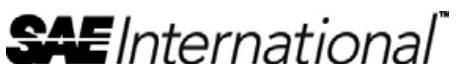

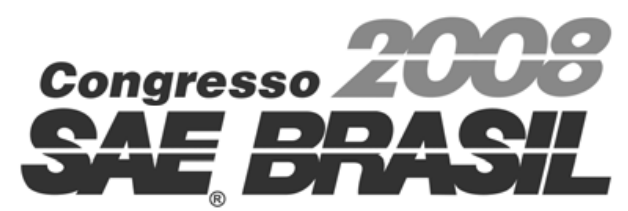

XVII Congresso e Exposição Internacionais da Tecnologia da Mobilidade São Paulo, Brasil 07 a 09 de outubro de 2008 
Properties advanced of the silicon nitride based ceramics and recent performance on automotive parts manufacture by machining process: Advanced Ceramics, demand Forecast

\author{
José Vitor Candido de Souza \\ Instituto Nacional de Pesquisas Espaciais - INPE/CTE/LAS \\ Maria do Carmo de Andrade Nono \\ Sergio Luiz Mineiro \\ Instituto Nacional de Pesquisas Espaciais - INPE/CTE/LAS
}

Olivério Moreira de Macedo Silva

AMR-CTA

Marcos Valério Ribeiro

UNESP-FEG

Copyright @ 2008 SAE International

\begin{abstract}
Automotive parts manufacture by machining process using silicon nitride-based ceramic tool development in Brazil already is a reality. $\mathrm{Si}_{3} \mathrm{~N}_{4}$-based ceramic cutting tools offer a high productivity due to their excellent hot hardness, which allows high cutting speeds. Under such conditions the cutting tool must be resistant to a combination of mechanical, thermal and chemical attacks. Silicon nitride based ceramic materials constitute a mature technology with a very broad base of current and potential applications. The best opportunities for $\mathrm{Si}_{3} \mathrm{~N}_{4}$-based ceramics include ballistic armor, composite automotive brakes, diesel particulate filters, joint replacement products and others. The goal of this work was to show latter advance in silicon nitride manufacture and its recent evolution on machining process of gray cast iron, compacted graphite iron and $\mathrm{Ti}$ 6Al-4V. Materials characterization and machining tests were analyzed by X-Ray Diffraction, Scanning Electron Microscopy, Vickers hardness and toughness fracture and technical norm. In recent works the authors has been proved to advance in microstructural, mechanical and physic properties control. These facts prove that silicon nitride-based ceramic has enough resistance to withstand the impacts inherent to the machining of gray cast iron (CI), compacted graphite iron (CGI) and Ti-6Al-4V (6-4).
\end{abstract}

\section{INTRODUCTION}

Machining is a major manufacturing process and plays a key role in the creation of wealth. Machining operations consumes a large amount of money annually worldwide. Over US\$ 100 billion is spent annually worldwide on metal part finishing processes such as turning, milling, boring and other cutting operations. It is also known that the machining industry converts about 10 $\%$ of all the metal produced into swarf (wastage). It is envisaged that up to $20 \%$ savings should be possible by using the correct choice of tooling and machining conditions [1]. The key benefits of machining can be the need for improving the technological performance of machining operations as assessed by tool-life, forces, power and surface finish has long been recognized to increase the economic performance of the machining operations.

Advanced ceramics have been studied extensively for application in automotive parts manufacture by machining process because they may improve dry machining and extend cutting tools life [2]. The benefits offered by ceramics over existing cemented carbides are attributed to the favorable material properties of ceramics, including lower density, superior strength at elevated temperatures [3]. The increasing attention to the environmental and health impacts of industry activities by governmental regulation and by the growing awareness in society is forcing manufacturers to reduce the use of lubricants. In the machining of automotive materials, classified as difficultto-machine materials, the consumption of cooling lubricant during the machining operations is very important. The associated costs of coolant acquisition, use, disposal and washing the machined components are significant, up to four times the cost of consumable tooling used in the cutting operations. To reduce the costs of production and to make the processes environmentally safe, the goal of the automotive manufacturers is to move toward dry cutting by eliminating or minimizing cutting fluids [4]. This goal can 
be achieved by a clear understanding of dry cutting function in machining operations, in particular in high speed cutting, and by the development and the use of new materials for tools. High speed cutting is another important aspect of advanced manufacturing technology introduced to achieve high productivity and to save machining cost. The combination of high speed cutting and dry cutting for difficult-to-cut automotive materials is the growing challenge to deal with the economic, environmental and health aspects of machining [5].

In this paper attention are focused on CI, CGI and $6 \mathrm{Al}-4 \mathrm{~V}$ dry machining presenting at recent works and advances concerning dry machining process.

\section{DEMAND FORECAST}

Recently United States have shown that advanced ceramics demand will grow seven percent annually through 2010. The best opportunities for ceramics include ballistic armor, ceramic composite automotive brakes, diesel particulate filters, joint replacement products and piezoceramic sensors. This study analyzes the $\$ 8.6$ billion US advanced ceramics industry. It presents historical demand data $(1995,2000,2005)$ and forecasts to 2010 and 2015 by type (e.g., alumina, zirconate, silicon carbide, silicon nitride); process and market (e.g., industrial machinery, transportation equipment, chemicals, pollution control). The study also considers market environment factors, details industry structure, evaluates company market share and profiles 30 major producers [6].

\section{WEAR MECHANISM OF CERAMIC CUTTING TOOLS}

In general, ceramic cutting tools undergo wear due to abrasion, adhesion or diffusion. The total tool wear observed in the ceramic cutting tool can be divided into two main broad categories [7]:

- Mechanically activated wear which includes abrasion, adhesion (attrition) and fracture;

- Chemically activated wear also called tribochemical wear which includes diffusion or dissolution wear.

Usually the wear in a cutting tool is a complex phenomenon and can be attributed to several of the above wear modes/mechanisms. The combined effect of the wear mechanisms or the predominance of any of them depends upon the following factors:

- type of cutting tool material such as single phase ceramic or composite ceramic, type of reinforcements like particles, whiskers, chemical affinity towards work piece material, mechanical properties such as hardness, toughness etc.;
- type of work piece material such as ferrous or nonferrous material, composite material, its hardness and machinability;

- cutting conditions such as speed, feed rate, depth of cut, and tool geometry such as rake angle, clearance angle, approach angle, cutting edge angle, nose radius etc.

In general ceramic cutting tool materials are more wear resistant than cemented carbide tools. Abrasive wear is predominantly controlled by the mechanical properties of tool material such as hardness and toughness. Diffusion wear is predominantly controlled by chemical stability and the solubility of the tool material in the work material at high temperature [2].

\section{DRY MACHINING}

Elimination of coolants also involves the absence of their positive effects on the metal cutting processes. For dry cutting operations, sufficient heat removal and the avoidance of heat build-up above a critical temperature must be guaranteed. The removal of chips from the cutting zone is another important aspect. The process must preserve the surface integrity of workpiece and produce stable tool wear suitable for automatic manufacturing systems. Tools with high hot hardness, high refractivity and low coefficients of friction are required and the use of tools with low-adhesion coatings can help greatly. Tool coatings play a major part in tool development, in particular for dry machining, Schulz et al. [8]. The tool coatings can at least partially substitute the eliminated functions of the cutting fluids.

The use of coolants, in addition to being undesirable to the environment and for the human health, entails high costs in production and disposal. Depending on the machined workpiece, cost savings up to $17 \%$ of the total workpiece cost can be made by introducing dry machining. This is mainly due to the elimination of coolant supply, cleaning, maintenance and disposal costs [9]. Reducing costs in the cutting process together with reduced environmental pollution by the use of dry machining is the main key for the industry to remain competitive and profitable in the future [10]. Today, wet cutting is still largely used in manufacturing industry, but research and development is being undertaken to minimize the use of coolant lubricants and new concepts of minimum quantity cutting fluid application have been developed [11].

\section{CUTTING TOOLS FOR MACHINING CI, CGI AND (6-4).}

The requirements for any cutting tool material used for machining compacted graphite iron [12]:

- good wear resistance,

- high hot hardness, 
- high strength and toughness,

- good thermal shock properties,

- adequate chemical stability at elevated temperature.

Turning and drilling are common operations carried out in the manufacture of cylinder heads and liners, while turning and drilling are the predominant machining operations in the manufacture of generation engine blocks.

\section{MACHINABILITY OF GRAY CAST IRON}

The presence of graphite particles in gray cast iron, renders this material to have good machinability by nearly all criteria, especially when compared to steels. Low rates of tool wear, high rates of metal removal, relatively low cutting forces and power consumption are the characteristics of cast iron. The surface of the machined cast iron, however, is rather matt in character. When machining gray cast iron the graphite particles determine cutting forces and surface roughness while the matrix determines the tool life [13, 14]. Therefore increasing cutting speed, better machinability is considered to be the most important gain. Although there is no definite information in the published literature that gray cast iron has better machinability than other materials. Data obtained from manufacturers like General Motors, show that parts manufactured from gray cast iron leads to improvement in tool life when compared to the heat treated forged steels. Very fine surface finishes can be obtained on gray cast iron. For machining gray cast iron, it is possible to find some practical cutting parameters value from the machining handbook $[15,16,17]$.

\section{MACHINABILITY COMPACTED GRAPHITE IRON}

Compacted graphite iron (CGI) is the material for the upcoming new generation of high power diesel-engines for cars. Due to its increased strength compared to grey cast iron (CI) it allows an increase in the cylinder-pressures and, therefore, a better fuel economy and a higher power output are also possible [18] and [19]. The reason why CGI was not used up to now in large scale production in the automotive industry is its difficult machinability as compared to CI, especially at high cutting speeds which are mandatory for large scale automotive production lines.

\section{MACHINABILITY TI-6AL-4V}

It is well known that titanium and its alloys are very difficult to machine because of their physical properties. One such property is the low thermal conductivity; hence the heat generated by the cutting action does not dissipate quickly. Another property is its strong alloying tendency or chemical reactivity with most tool materials, which causes rapid destruction of the cutting tool with galling, welding and smearing at the interacting surface. In conventional titanium machining, some basic rules have been developed, such as using low cutting speeds, high feed rates and copious amounts of cutting fluid [20]. Many researchers around the world have been seeking effective methods to machine titanium alloys.

\section{EXPERIMENTAL PROCEDURE}

The $\mathrm{Si}_{3} \mathrm{~N}_{4}$-based compositions were prepared using the following high purity starting powders. For simplicity reasons, in this work they will be referred as A, B and C, respectively, conform are shown in Table 1 . In this work, cutting tools were produced using powders of $\alpha-\mathrm{Si}_{3} \mathrm{~N}_{4}$ (Grade M11, H.C. Starck), $\alpha-\mathrm{Al}_{2} \mathrm{O}_{3}$ (Grade A16SG, Alcoa Chemicals, USA), $\mathrm{Y}_{2} \mathrm{O}_{3}$ (Grade C-Fine, H.C. Starck), $\mathrm{CeO}_{2}$ (Grade C-Fine, H.C. Starck) and AlN (Grade C, H.C. Starck). Suspensions comprising $100 \mathrm{~g}$ of appropriate powder mixture were prepared. The suspensions were planetary-milled in an $\mathrm{Al}_{2} \mathrm{O}_{3}$ cube (i.e., milling container) for $3 \mathrm{~h}$, using $250 \mathrm{~g}$ of $\mathrm{Al}_{2} \mathrm{O}_{3}$ balls of different sizes. The weight loss of the $\mathrm{Al}_{2} \mathrm{O}_{3}$ balls and the cube was always measured. The results indicated that the contamination level introduced in this stage was $<0.2 \%$. After drying $\left(100{ }^{\circ} \mathrm{C}\right.$, $24 \mathrm{~h})$, the powders were sieved (100 mesh). Samples $(16.36 \mathrm{~mm} \times 16.36 \mathrm{~mm} \times 7.5 \mathrm{~mm})$ were prepared by uniaxial pressing $(50 \mathrm{MPa})$ following by isostatic pressing (300 $\mathrm{MPa}, 2 \mathrm{~min})$. The green samples were embedded in a mixture of powders of $\mathrm{Si}_{3} \mathrm{~N}_{4}$ and $\mathrm{BN}$ (70: 30 weight ratio) inside a graphite crucible and sintered at $1850{ }^{\circ} \mathrm{C}$ for $2 \mathrm{~h}$, in nitrogen atmosphere $(0.1 \mathrm{MPa})$ with a heating rate of 25 ${ }^{\circ} \mathrm{C} / \mathrm{min}$.

Table 1. Presents the compositions and green densities

\begin{tabular}{|l|c|c|l|l|l|l|}
\hline $\begin{array}{l}\text { Samples } \\
(\text { wt.\%) }\end{array}$ & $\mathrm{Si}_{3} \mathrm{~N}_{4}$ & $\mathrm{AlN}$ & $\mathrm{CeO}_{2}$ & $\mathrm{Al}_{2} \mathrm{O}_{3}$ & $\mathrm{Y}_{2} \mathrm{O}_{3}$ & $\begin{array}{c}\text { Green } \\
\text { density } \\
(\%)\end{array}$ \\
\hline $\mathbf{A}$ & 80.00 & 12.00 & - & - & 8.00 & $\begin{array}{l}60.00 \\
\pm 0.20\end{array}$ \\
\hline $\mathbf{B}$ & 82.86 & 10.63 & - & - & 6.51 & $\begin{array}{l}60.13 \\
\pm 0.08\end{array}$ \\
\hline $\mathbf{C}$ & 77.90 & 10.00 & 4.80 & 2.50 & 4.80 & $\begin{array}{l}59.80 \\
\pm 0.15\end{array}$ \\
\hline
\end{tabular}

\section{MATERIALS}

Materials used in the experiments were compacted graphite iron, gray cast iron and Ti-6Al-4V alloy in the form of round bar 80, 105 and $93 \mathrm{~mm}$ in diameter and 400, 300 and $97 \mathrm{~mm}$ in length respectively. The measurement of the hardness is usual procedure to get information about the mechanical properties of materials. Brinell hardness can be related to the tensile strength of materials [21, 22, 23]. With a measured hardness of $246 \pm 3$ Brinell hardness number (BH) to compacted graphite iron, $205 \pm 2$ Brinell hardness number $(\mathrm{BH})$ to gray cast iron and $45 \pm 1 \mathrm{HRc}$ to Ti-6Al-4V alloy (average of five readings). The chemical composition of the material is given in Table 2 . 
Table 2. Elements principal of chemical composition of (CI), (CGI) and (6-4).

\begin{tabular}{|c|l|l|l|l|l|l|}
\hline $\begin{array}{c}\text { Elem. } \\
\text { (CGI) }\end{array}$ & $\mathbf{C}$ & $\mathbf{S i}$ & $\mathbf{C u}$ & $\mathbf{T i}$ & $\mathbf{M n}$ & $\mathbf{F e}$ \\
\hline Wt (\%) & 3.62 & 2.47 & 0.72 & 0.012 & 0.16 & Bal. \\
\hline $\begin{array}{c}\text { Elem. } \\
(\mathbf{C I})\end{array}$ & $\mathbf{C}$ & $\mathbf{S i}$ & $\mathbf{M n}$ & $\mathbf{S}$ & $\mathbf{C r}$ & $\mathbf{F e}$ \\
\hline Wt (\%) & 3.04 & 2,58 & 0.42 & 0.11 & 0.07 & Bal. \\
\hline $\begin{array}{c}\text { Elem. } \\
(\mathbf{6 - 4})\end{array}$ & $\mathbf{A l}$ & $\mathbf{V}$ & $\mathbf{F e}$ & $\mathbf{S i}$ & $\mathbf{C}$ & $\mathbf{T i}$ \\
\hline Wt (\%) & $\begin{array}{l}5.2- \\
6.4\end{array}$ & $\begin{array}{l}3.5- \\
4.4\end{array}$ & 0.32 & 0.14 & 0.10 & Bal. \\
\hline
\end{tabular}

\section{CUTTING PERFORMANCE}

The goal of this experimental work was to investigate the effects of cutting parameters on tool wear, temperature and surface roughness of the gray cast iron (CI), compacted graphite iron (CGI) and Ti-6Al-4V (6-4). In order for this, cutting speed, feed rate and depth of cut were chosen as process parameters. The turning tests were conducted in dry conditions on a computer numerical control lathe (CNCRomi, Mod. Centur 30D) having a maximum spindle speeds of $4000 \mathrm{rpm}$ and a maximum power of $20 \mathrm{~kW}$.

The cutting inserts were of SNGN120408 (12.7 $\mathrm{mm} \times 12.7 \mathrm{~mm}, 4.76 \mathrm{~mm}$ thickness) type and the tool holder was of CSRNR $2525 \mathrm{M}$ 12CEA type (offset shank with $15^{\circ}$ $\left[75^{\circ}\right]$ side cutting edge angle, $0^{\circ}$ insert normal clearance and $25 \mathrm{~mm} \times 25 \mathrm{~mm} \times 150 \mathrm{~mm}$ ) type. The cutting edge had the same preparation consisting in a chamfer at $-20^{\circ}$ and an edge hone of $0.20 \mathrm{~mm}$ radius. For machining tests was used a ceramic cutting tool which giving the best physics and mechanical properties. Three levels were specified for each process parameter on gray cast iron, compacted graphite iron and Ti-6Al-4V as given in Table 3. The parameter levels were chosen within the intervals recommended by literature $[23,24,25]$. The flank wear of the insert was measured using a toolmakers microscope and SEM. The surface roughness of the machined workpiece was measured using a surface roughness meter with a cut-off length of $0.8 \mathrm{~mm}$ and sampling length of $5 \mathrm{~mm}$ (Mitutoyo Surftest 402 series 178). The measured the cutting temperature in cutting tool/work-piece interface it was used an infrared pyrometer fixed in the carriage and $20 \mathrm{~cm}$ from cutting-edge (without physical contact). For each condition the cutting test was repeated twice.

Table 3 Assignment of the levels to the factors

\begin{tabular}{|l|c|c|c|}
\hline Level & $\begin{array}{l}\text { Cutting } \\
\text { speed } \\
\boldsymbol{V}_{\mathbf{c}}(\mathbf{m} / \mathbf{m i n})\end{array}$ & $\begin{array}{l}\text { Feed rate } \\
\boldsymbol{f}(\mathbf{m m} / \mathbf{r e v})\end{array}$ & $\begin{array}{l}\text { Depth of cut } \\
\boldsymbol{a}_{\mathbf{p}}(\mathbf{m m})\end{array}$ \\
\hline $\mathrm{A} \rightarrow \mathrm{CI}$ & 300 & 0,32 & 1,00 \\
\hline $\mathrm{B} \rightarrow \mathrm{CI}$ & 500 & 0,32 & 3,00 \\
\hline
\end{tabular}

\begin{tabular}{|l|c|c|c|}
\hline $\mathbf{C} \rightarrow$ CI & 800 & 0,32 & 2,00 \\
\hline $\mathbf{D} \rightarrow$ CGI & 200 & 0,2 & 0,50 \\
\hline $\mathbf{E} \rightarrow$ CGI & 300 & 0,2 & 1,00 \\
\hline $\mathbf{F} \rightarrow$ CGI & 500 & 0,2 & 1,00 \\
\hline $\mathbf{G} \rightarrow 6-4$ & 85 & 0,10 & 0,50 \\
\hline $\mathbf{H} \rightarrow 6-4$ & 120 & 0,05 & 0,50 \\
\hline $\mathbf{I} \rightarrow 6-4$ & 180 & 0,20 & 0,50 \\
\hline
\end{tabular}

\section{RESULTS OF CUTTING TOOLS PROPERTIES}

\section{RELATIVE DENSITIES AND WEIGHT LOSS OF CERAMICS CUTTING TOOLS}

The green densities of inserts have been $\geq 59.80 \%$ of theoretical density. The relative densities of the samples after sintering presented values higher than $97 \%$ of theoretical density. It is due to characteristics liquid formed during sintering process and sintering parameters used. In samples A and B important results of relative density and weight loss were obtained because of the characteristics of additives (AlN $/ \mathrm{Y}_{2} \mathrm{O}_{3}$ ), which have has good chemical stability and properties inherent to liquid formed, such as viscosity, which influence directly in $\mathrm{LPS}-\mathrm{Si}_{3} \mathrm{~N}_{4}$ mechanisms, particle rearrangement and solutionreprecipitation mainly, responsible by decrease of the porosity and consequent increase of relative density. The weight loss observed at sample (C) utilizing AlN/ $\mathrm{Al}_{2} \mathrm{O}_{3} / \mathrm{Y}_{2} \mathrm{O}_{3} / \mathrm{CeO}_{2}$ probable is due to possible volatilization of $\mathrm{CeO}_{2}$ and organics material, utility to compaction. Hence, this weight loss is promoted by the high temperature in the sintering process in sample (C).

\section{PHASE ANALYSIS OF THE SINTERED SAMPLES}

The X-ray diffraction pattern of samples designated as A, B and $\mathrm{C}$ sintered at $1850{ }^{\circ} \mathrm{C}$ is shown in Figs. 1, 2 and 3. The majoritary $\alpha$-SiAlON phase was identified in Fig. 1 and Fig. 2, suggesting the existence of a sintering complete system. These Figs shows the relationship between the phase formation and additives amount which will reflect in the increase of mechanical properties and phase $\mathrm{Y}_{2} \mathrm{Si}_{3} \mathrm{O}_{3} \mathrm{~N}_{4}$ appears or disappears. A higher sintering temperature of $1850^{\circ} \mathrm{C}$ and a $20 \%$ additive amount was an effective procedure to improve the mechanical properties and reduce intergranular phase. Therefore, in this work, samples content $\mathrm{Y}_{2} \mathrm{O}_{3} / \mathrm{AlN}$ as sintering additives were densified completely presenting majoritary $\alpha$-SiAlON phase. This is coincident with the results presented by Santos et al.[26]. Whereas, the sample additived for $\mathrm{AlN} / \mathrm{Al}_{2} \mathrm{O}_{3} / \mathrm{Y}_{2} \mathrm{O}_{3} / \mathrm{CeO}_{2}$, Fig. 3 has been noted predominant $\beta-\mathrm{Si}_{3} \mathrm{~N}_{4}$ phase. It's due to the liquid phase formation, in association with the isothermal holding time and sintering pressure used, which influenced in obtaining of dense ceramics with elongated $\beta$ $\mathrm{Si}_{3} \mathrm{~N}_{4}$ grains $(2.5 \mu \mathrm{m})$ with high aspect ratio (higher \pm 6 ), in an complete $\alpha-\beta$ transformation and a rigid and intergranular phase resistant to crack propagation. The phase of $\mathrm{Y}_{2} \mathrm{Si}_{3} \mathrm{O}_{3} \mathrm{~N}_{4}$ was identified from the XRD spectra 
and the formation of this phase can be explained by the following reaction equation.

$$
\mathrm{Y}_{2} \mathrm{O}_{3}+\mathrm{Si}_{3} \mathrm{~N}_{4} \rightarrow \mathrm{Y}_{2} \mathrm{Si}_{3} \mathrm{O}_{3} \mathrm{~N}_{4}
$$

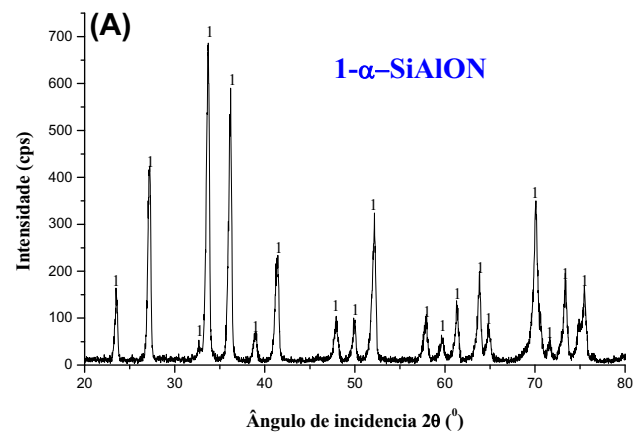

Fig. 1. X-ray diffraction patterns of sample (A).

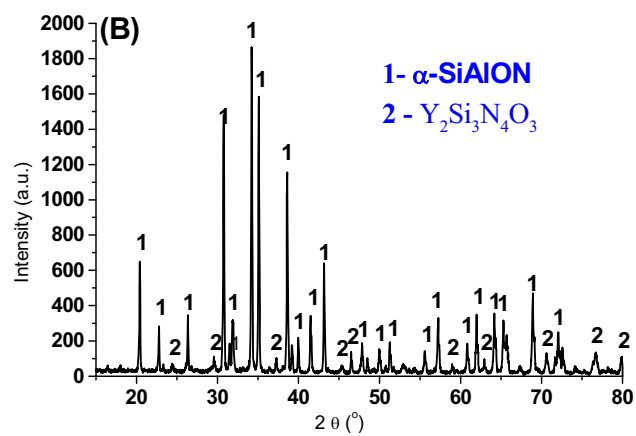

Fig. 2. X-ray diffraction patterns of sample (B).

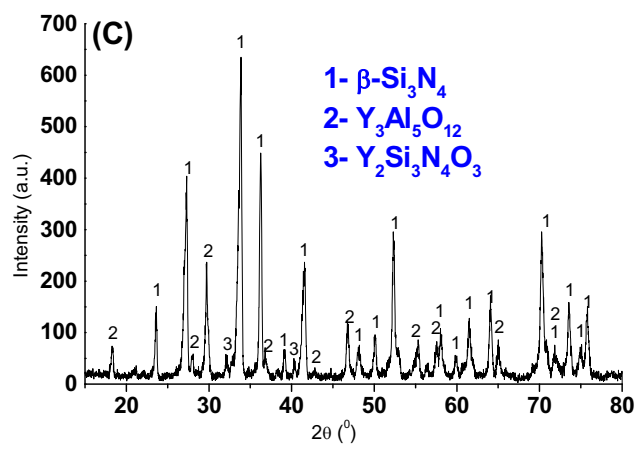

Fig. 3. X-ray diffraction patterns of sample (C).

\section{HARDNESS AND FRACTURE TOUGHNESS}

Fracture toughness and hardness of the sintered samples are shown in Tab. 4. The samples additived for $\mathrm{AlN} / \mathrm{Y}_{2} \mathrm{O}_{3}$ showed the larger hardness values, because presence of $\alpha$-SiAlON phase. The same samples too showed the low fracture toughness values, because probably of microstructure or same of high hardness, that it is inversely proportional to the fracture toughness. Whereas, for the samples additived for $\mathrm{AlN} / \mathrm{Al}_{2} \mathrm{O}_{3} / \mathrm{Y}_{2} \mathrm{O}_{3} / \mathrm{CeO}_{2}$ has been noted inverse behavior with lowest hardness and largest fracture toughness values. The high fracture toughness of the sample (C) is explained by the microstructure, consisting of elongated grains with high aspect ratio, which act as crack propagation barriers, increasing the energy consumed during crack growth. It is well known that the anisostropic growth of $\beta-\mathrm{Si}_{3} \mathrm{~N}_{4}$ grains is related to the different growth velocities of the basal plane and the lateral planes of the hexagonal $\beta-\mathrm{Si}_{3} \mathrm{~N}_{4}$ prism, due to the different specific surface energies of each plane. However this result is explained by the grain growth velocity of the $\beta-\mathrm{Si}_{3} \mathrm{~N}_{4}$ grains because of additives viscosity in temperature at $1850{ }^{\circ} \mathrm{C}$. However the properties presented by three samples were satisfactory and promising for applications as cutting tools, resulting also in an improvement of the properties when compared to earlier works $[27,28,29]$. It has been verified that the use of the additives mixtures investigated in this work under the sintering conditions described, resulted in high values of hardness and fracture toughness, allowing to interesting applications. The geometrics of $\alpha$-SiAlON cutting tools development in this paper are showed in Fig.4.

Table 4. Presents the cutting tools properties: density relatives, weight losses, Vickers hardness and fracture toughness.

\begin{tabular}{|c|c|c|c|c|}
\hline Samples & $\begin{array}{l}\text { Vickers } \\
\text { hardness } \\
(\mathrm{GPa})\end{array}$ & $\begin{array}{l}\text { Fracture } \\
\text { toughness } \\
\mathrm{K}_{\mathrm{ic}} \\
\left(\mathrm{MPa} \cdot \mathrm{m}^{1 / 2}\right)\end{array}$ & $\begin{array}{l}\text { Relative } \\
\text { density } \\
(\%)\end{array}$ & $\begin{array}{l}\text { Weight } \\
\text { loss } \\
(\%)\end{array}$ \\
\hline $\mathbf{A}$ & $\begin{array}{l}20.32 \pm \\
0.21\end{array}$ & $5.36 \pm 0.18$ & $\begin{array}{l}98.16 \pm \\
0.12\end{array}$ & $\begin{array}{l}2.10 \pm \\
0.15\end{array}$ \\
\hline B & $\begin{array}{ll}19.38 \quad \pm \\
0.42 & \end{array}$ & $5.62 \pm 0.35$ & $\begin{array}{l}98.50 \pm \\
0.28\end{array}$ & $\begin{array}{l}1.98 \pm \\
0.34\end{array}$ \\
\hline $\mathbf{C}$ & $\begin{array}{ll}18.45 \quad \pm \\
0.36\end{array}$ & $6.01 \pm 0.40$ & $\begin{array}{l}97.95 \pm \\
0.16\end{array}$ & $\begin{array}{l}3.50 \pm \\
0.23\end{array}$ \\
\hline
\end{tabular}

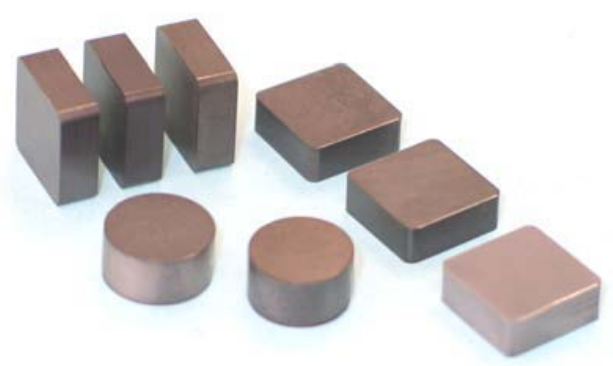

Fig. 4. Photograph of $\alpha$-SiAlON cutting tools development in Brazilian laboratory. 


\section{RESULTS OF MACHINING PERFORMANCE}

\section{EFFECTS OF CUTTING SPEED ON TOOL LIFE OF CGI}

As the tool life criteria, a value of $0.6 \mathrm{~mm}$ of average flank wear land $\left(\mathrm{VB}_{\mathrm{B}}\right)$ for sintered cutting tool was used. During the experiments, the cutting processes were paused in each pass for the average flank wear was measured. The cutting speeds $(V c)$ present different effects onto the tool life, tool wear, temperature and surface quality. The cutting tools were analyzed by SEM and optical microscopy. In the experiments in which the cutting speeds varies, as the cutting speed changes the tool life too. In this paper performance of $\alpha$-SiAlON cutting tool in turning on compacted graphite iron was observed in Fig. 5. In this figure can been noted that flank wear of $\alpha$-SiAlON is lower to $V_{c}=300 \mathrm{~m} / \mathrm{min}, a_{p}=1.00 \mathrm{~mm} / \mathrm{rev}$, due to better stabilization/accommodation between cutting tool/workpiece, it can been confirmed in the Fig. 6 (Photomicrography). During on turning compacted graphite iron the stability of the $\alpha$-SiAlON cutting tool is favored by the cut depth $\left(a_{p}\right)$ and cutting speed $\left(V_{c}\right)$. The suitable machining conditions becomes of further help. The wrong selections conditions machining of compacted graphite iron are expected to prove worse wear behavior and low cutting tools performance. Analyzing Fig. 5 and Fig. 7, it is possible to suppose that lower cutting speed $\left(\mathrm{V}_{\mathrm{c}}=200\right.$ $\mathrm{m} / \mathrm{min}, a_{\mathrm{p}}=0.50 \mathrm{~mm} / \mathrm{rev}$ ) provides minor machining length due to unstable machining conditions which cause to increasing wear rate and possible vibrations could be attributed to the increased severity which evident surface damage. For higher cutting speed $\left(\mathrm{V}_{\mathrm{c}}=500 \mathrm{~m} / \mathrm{min}, \mathrm{a}_{\mathrm{p}}=1.00\right.$ $\mathrm{mm} / \mathrm{rev}$ ) provides shorter machining length due to high mechanical stresses applied that exceed the glass phase strength and promote different wear mechanisms Fig. 5 and Fig. 8.

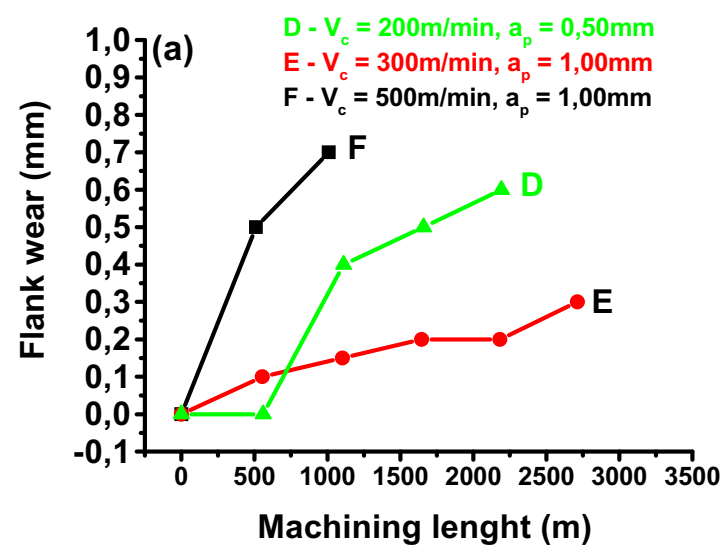

Fig.5. Flank wear (Vb vs machining length (m).

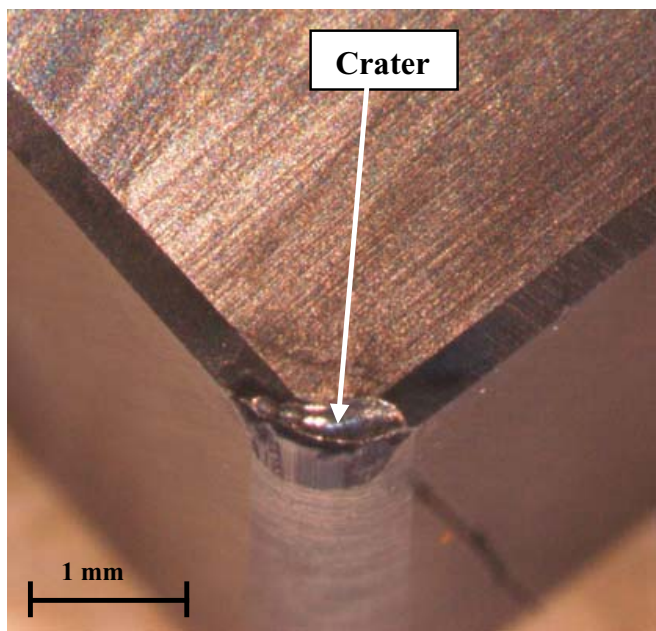

Fig. 6. Photomicrograph of the wear profile to $V_{c}=300$ $\mathrm{m} / \mathrm{min}, a_{p}=1.00 \mathrm{~mm} / \mathrm{rev}$.

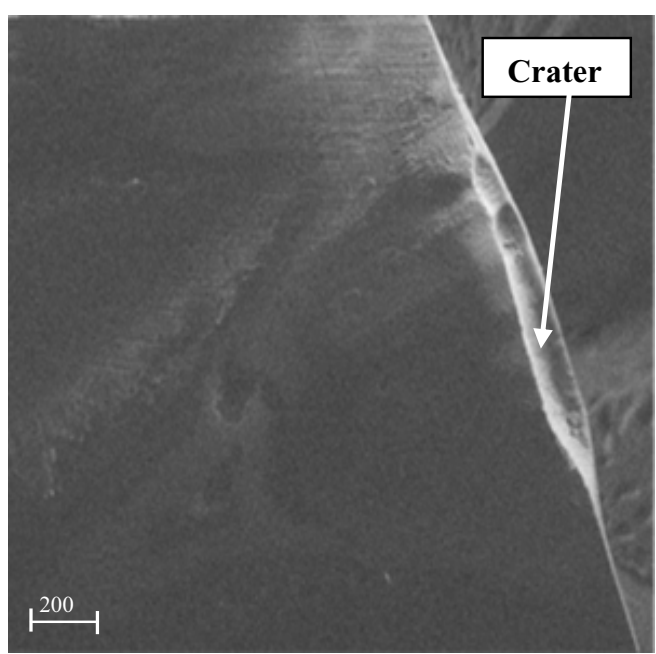

Fig. 7. Photomicrograph of the wear profile to $V_{c}=200$ $\mathrm{m} / \mathrm{min}, a_{p}=0.50 \mathrm{~mm} / \mathrm{rev}$.

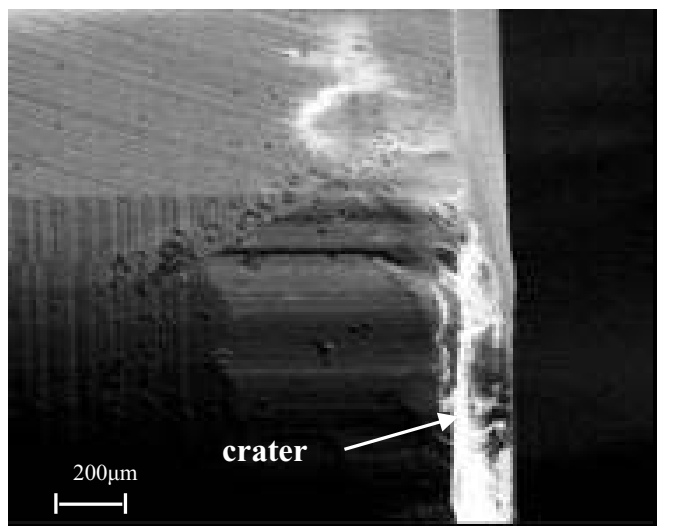

Fig. 8. Photomicrograph of the wear profile to $V_{c}=500$ $\mathrm{m} / \mathrm{min}, a_{p}=1.00 \mathrm{~mm} / \mathrm{rev}$. 


\section{MECHANISMS WEAR ON COMPACTED GRAPHITE IRON MACHINING}

In the compacted graphite iron machining, different modes of tool failure including rake face wear and flank wear. These tool wear patterns in turning compacted graphite iron suggested that the tool wear mechanisms were diffusion, attrition, and wear by possibly chemical interaction. For all conditions the cutting tools evidenced mechanical and chemical wear. Mechanical wear is revealed by abrasion and adhesion, when the chemical wear is revealed by possible phase transformations into crater and diffusion. The temperature in the cutting zone was measured and present a value of about $742-920{ }^{\circ} \mathrm{C}$ can be expected, as see Fig. 9. The high temperature developed in cut zone promotes different wear mechanisms. SEM micrographs depicted in Fig. 10 and Fig. 11 shows two different worn inserts.

In the Fig.7 (above), illustrates the rake face of insert. This insert correspond to the tests made at $200 \mathrm{~m} / \mathrm{min}$ and $0.50 \mathrm{~mm}$ of depth-of-cut. The SEM showed crater wear predominant. The presence of crater in the rake face of the cutting tool is a clear evidence of the abrasion and adhesion mechanisms caused by interactions between workpiece/tool materials. In this figure the tool wear on the rake face occurred in the form of a pit called the crater, which was formed at little distance from the cutting edge.

For the high-speed machining $(500 \mathrm{~m} / \mathrm{min}$ and $1.00 \mathrm{~mm}$ of depth-of-cut), tool wear on the rake face predominates too and therefore tool life is determined with the wear deepening. Tool wear on the rake face when in the high-speed turning of compacted graphite iron using $\alpha$ SiAlON ceramic tool is shown in Fig. 8. This figure showed that increasing the cutting speed even further led to the increase of the wear area. This mode of tool wear is mainly due to too high cutting temperature on the rake face. Extreme high cutting speed leads to very high temperature $\left(912-920^{\circ} \mathrm{C}\right.$ ) occurring at the vicinity of the main cutting edge where the maximum depth of tool wear on rake face occurs, as see Fig. 9 (below). The hardness of inter-granular phase of the tool materials decreases at such high cutting temperatures, which aggravates the abrasive wear on tool rake face, as see Fig. 12. The high cutting temperature also resulted in possibly diffusion, micro-adhesion, microplastic deformation, etc. The tool-chip contact length is shorter in high-speed machining causes the cutting force to be concentrated adjacent to the main cutting edge. The softer cutting edge due to high temperature under the concentrated cutting force near the cutting edge leads to micro-deformation and micro-deflection.

For the medium-speed machining $(300 \mathrm{~m} / \mathrm{min}$ and $1.00 \mathrm{~mm}$ of depth-of-cut), mechanical wear modes include intergranular fracture and grain boundary fatigue at the interface between $\alpha$-SiAlON grains and glass phase on and below the surface. Furthermore, the elongation of these cracks below the surface may lead to the microdelamination of region surface below. The tribochemical reactions of $\alpha$-SiAlON cutting tools lead to the formation of phases such as $\mathrm{SiO}_{2}$ and $\mathrm{SiO}_{x} \mathrm{~N}_{y}$. Under high temperature, tribochemical reactions are dominating wear mechanisms. The worn surface in center crater wear shows cavities in the order of the short grain size of $\alpha-\mathrm{SiAlON}$. This may result from intergranular fracture at the interfaces $\mathrm{Si}_{3} \mathrm{~N}_{4} /$ glass phase, and subsequent pull-out of tool particles. The $\alpha$ SiAlON cutting tools generate very smooth, agglomerated and attached to each other. The wear debris has both spherical and irregular shape and the loose wear debris occur to during the worn surfaces on $V_{c}=300 \mathrm{~m} / \mathrm{min}$, $\mathrm{a}_{\mathrm{p}}=1.00 \mathrm{~mm} / \mathrm{rev}$, as see Fig. 10 and Fig. 11 .

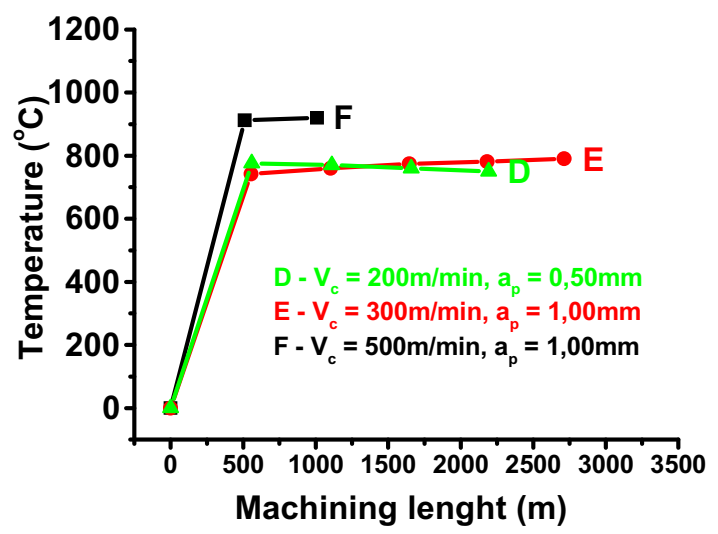

Fig. 9. Temperature (T) vs. machining length (m).

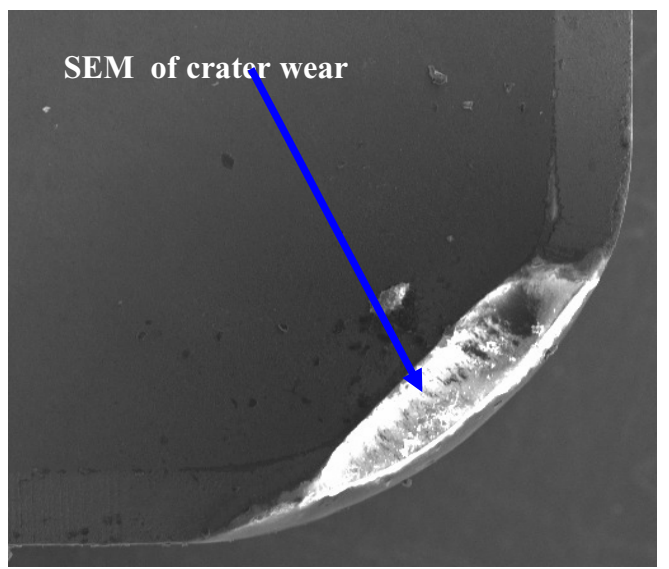

Fig 10. Photomicrograph of the crater wear to $V_{c}=300$ $\mathrm{m} / \mathrm{min}, a_{p}=1.00 \mathrm{~mm} / \mathrm{rev}$. 


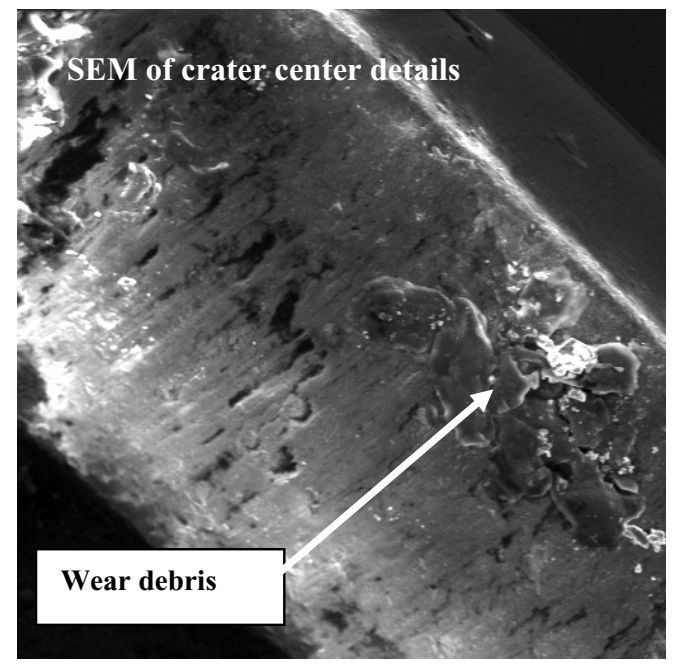

Fig. 11. Surface morphology of the crater at $V_{c}=300$ $\mathrm{m} / \mathrm{min}, a_{p}=1.00 \mathrm{~mm} / \mathrm{rev}$.

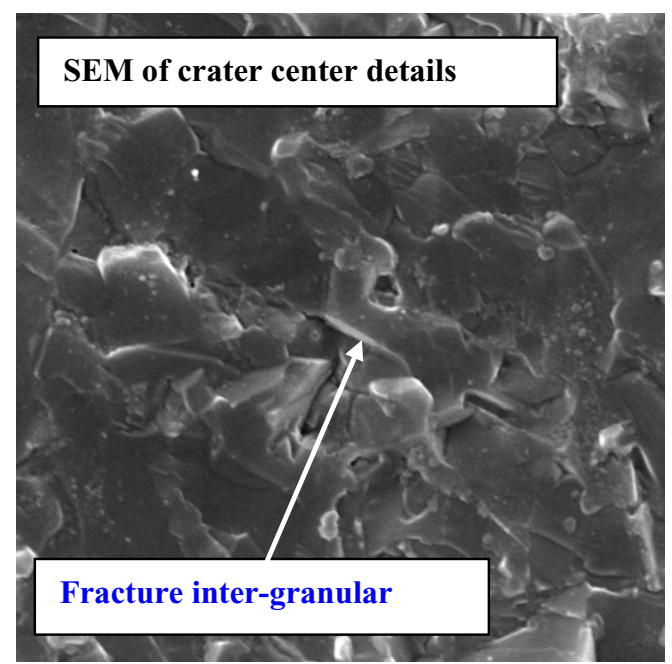

Fig. 12. Surface morphology of the crater at $V_{c}=500 \mathrm{~m} / \mathrm{min}$, $a_{p}=1.00 \mathrm{~mm} / \mathrm{rev}$.

\section{SURFACE FINISH ON COMPACTED GRAPHITE IRON}

In the Figs. 13 and 14 shown the workpiece surface roughness values for compacted graphite iron machining. These values are the averages of three readings. It is seen from Figs. 13 and 14 that cutting speed $\left(V_{c}\right)$ and cut depth $\left(a_{\mathrm{p}}\right)$ had a significant influence on the surface roughness produced. These figures shows that the highest surface roughness values are observed on $V_{c}=200 \mathrm{~m} / \mathrm{min}, a_{p}=0.50$ $\mathrm{mm} / \mathrm{rev}$. The general trend in the curves in Figs. 13 and 14 is that when cut depth $\left(a_{\mathrm{p}}\right)$ is increased the surface roughness values decrease. The increase on surface roughness with decreasing of the cutting speed $\left(V_{c}\right)$ and cut depth $\left(a_{p}\right)$ can be attributed to wrong stabilization/ accommodation between cutting tool/workpiece. However, the surface quality obtained with conditions D and E, tends to stabilize with increasing cutting length which is related to progression of flank wear. It is therefore difficult to draw general conclusions from these results about the influence of cutting speed $\left(V_{c}\right)$ and cut depth $\left(a_{p}\right)$ on surface roughness. As a matter of fact surface roughness is quite a complicated subject. Many other factors besides machining conditions may have some effect on the quality of machined surfaces, for example inhomogeneity of cast materials, random distribution of graphite nodules, etc.

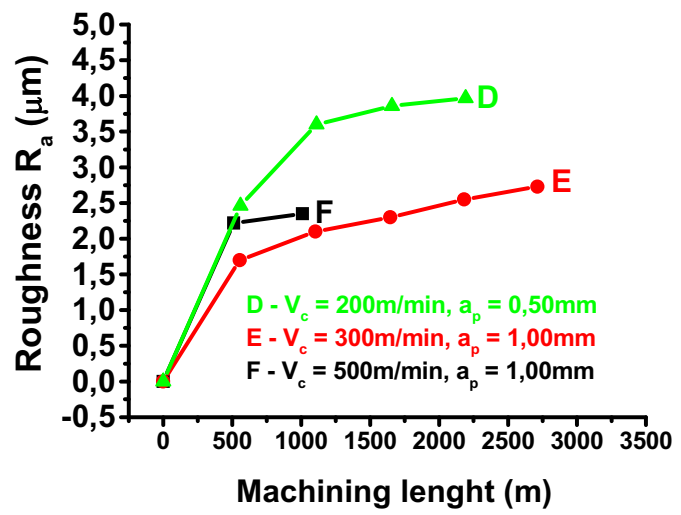

Fig. 13. Surface roughness $\left(R_{a}\right)$ vs. machining length (m).

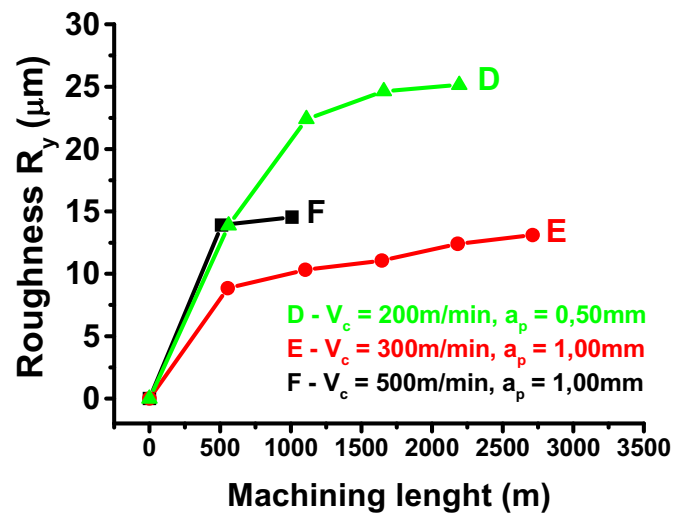

Fig. 14. Surface roughness (Ry) vs. machining length (m).

\section{MACHINING PERFORMANCE ON GRAY CAST IRON}

In the experiments of $\alpha$-SiAlON cutting tools were taken into consideration throughout their tool life at certain cutting speeds. The flank wear was measured in connection to machining length and for different values of cutting speeds. A number of experiments were conducted in the desired range of process parameters, viz variant cutting speeds $(v)$, constant feed $(f)$ and different depths of cut $\left(a_{p}\right)$. The variation of flank wear of the $\alpha$-SiAlON cutting tools with respect to machining length is shown in Fig.15, Fig.16, Fig.17 and Fig. 18. In the Fig. 15, can has been noted that flank wear of $\alpha$-SiAlON is lower to $V_{c}=500 \mathrm{~m} / \mathrm{min}, a_{p}=3.00$ 
$\mathrm{mm} / \mathrm{rev}$, due to better stabilization/accommodation between cutting tool/workpiece, it can be confirmed in the Fig. 16. For this machining condition on gray cast iron turning, the stability of the $\alpha$-SiAlON cutting tool is favored in the presence of a lubricating phase, like graphite flakes. In the gray cast iron machining, since the workpiece is a good conductor of heat, a major portion of the heat developed at the cutting zone has to be dissipated by the tool and chip. Therefore, the dependence of temperature on machining conditions will exert a greater influence on the tool performance, as see Fig. 19. However with lower order cutting velocity, the cutting wedge of the tool tends to plow on to the work surface resulting in a marginally higher order force, as see Fig. 17 and confirmed Fig. 15. As the cutting speed and depth increases, the cutting becomes steadier due to heat concentration area, which promote a consequent reduction in cutting force components and the presence of graphite particles in gray cast iron renders these materials to have good machinability by nearly all criteria, especially when compared to other materials, facts confirmed in Fig. 16. Low rates of tool wear, high rates of metal removal, relatively low cutting forces and power consumption are the characteristics of gray cast iron machining with $\alpha$-SiAlON cutting tool. Therefore, in this work the higher $\left(V_{c}=800 \mathrm{~m} / \mathrm{min}\right)$ cutting speed provide minor machining length than to $V_{c}=300 \mathrm{~m} / \mathrm{min}$. It's due to increase cutting speed and low cut depth, which difficult adhering capability to the lubricant particles on the sliding surfaces, causing increasing wear rate and possible vibrations that could be attributed to the increased severity of evident surface damage of cutting tool. The reports results of the $\alpha$-SiAlON cutting tools when machining gray cast iron showed similar micrographics, independent of conditions, conform observed by authors in others works [REF]. It's confirm the important performance this cutting tools on machining gray cast iron.

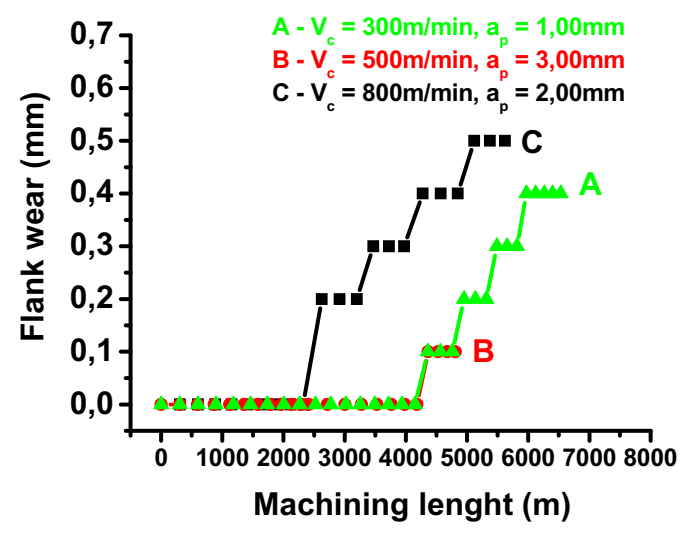

Fig. 15. Flank wear (Vb vs machining length (m).

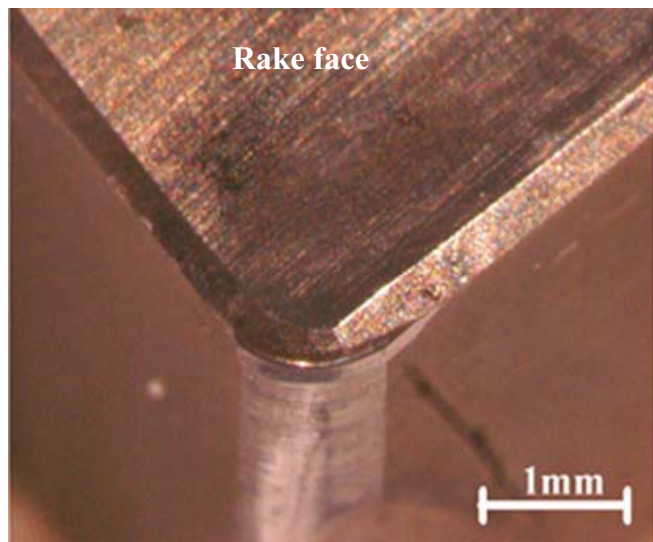

Fig. 16. Photomicrograph of the wear profile to $V_{c}=500$ $\mathrm{m} / \mathrm{min}, a_{p}=3.00 \mathrm{~mm} / \mathrm{rev}$.

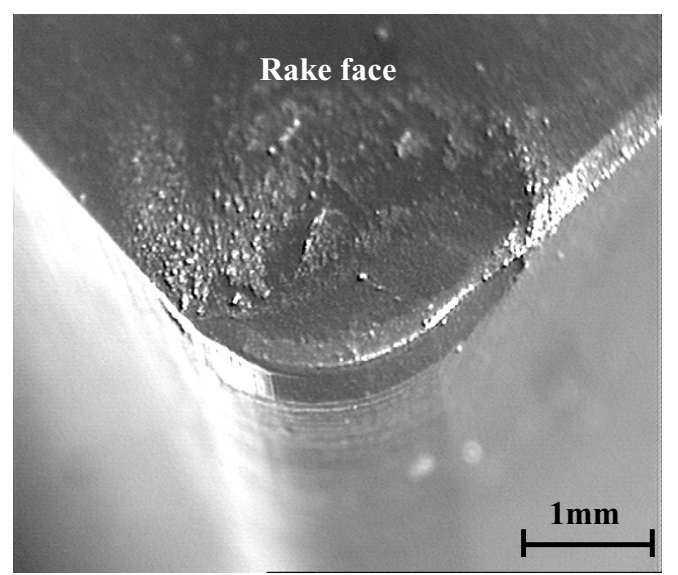

Fig. 17. Photomicrograph of the wear profile to $V_{c}=300$ $\mathrm{m} / \mathrm{min}, a_{p}=1.00 \mathrm{~mm} / \mathrm{rev}$.

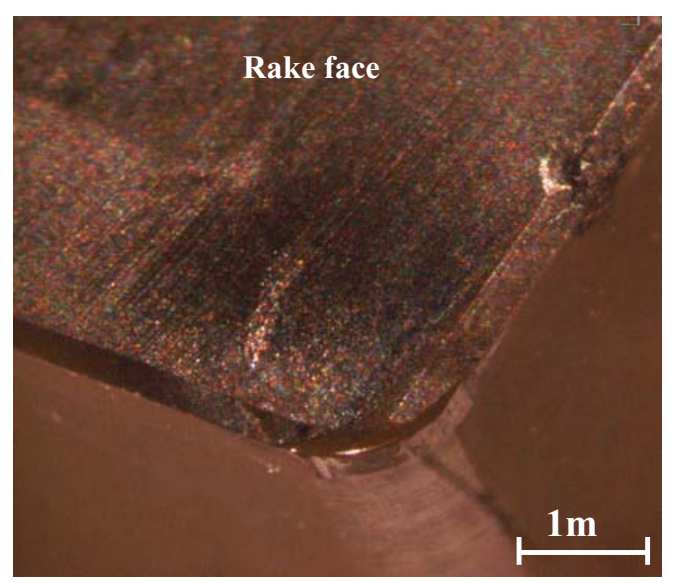

Fig. 18. Photomicrograph of the wear profile to $V_{c}=300$ $\mathrm{m} / \mathrm{min}, a_{p}=1.00 \mathrm{~mm} / \mathrm{rev}$. 


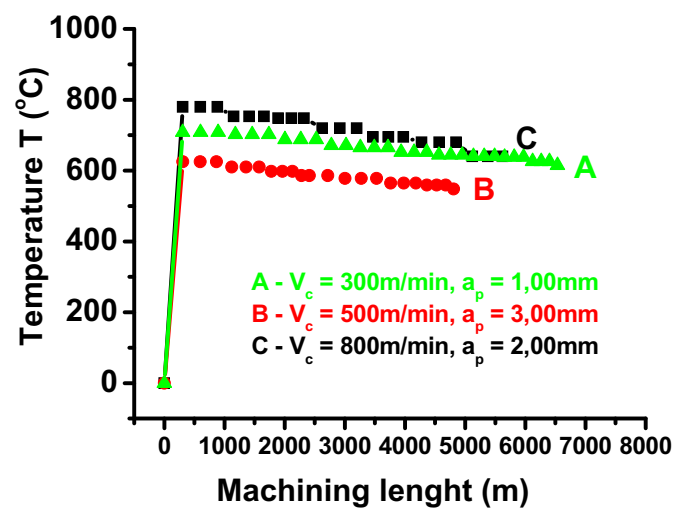

Fig. 19. Temperature (T) vs. machining length (m).

\section{EFFECTS OF THE SURFACE ROUGHNESS}

Experiments on surface roughness were conducted for three different cutting speeds. The $R_{\mathrm{a}}$ and $R_{\mathrm{y}}$ values obtained from the experiments were compared. Observed changes in $R_{\mathrm{a}}$ and $R_{\mathrm{y}}$ values with respect to cutting speeds and cut depth are shown in Fig. 20 and Fig 21. The quality of a machined surface, especially in turning, depends largely on the form stability of the cutting tools. During turning, the cutting tool replicates its nose on the work surface, resulting in the formation of the surface texture. From the surface texture point of view, an ideal tool is one that is able to sustain the replication of the cutting nose. Hence, the performance of the tool or the quality of the machined surface texture is largely dependent on the form stability of the cutting tool. In this work similar comportment was observed during the machining test to conditions $\mathrm{B}$ and $\mathrm{C}$, which showed a little change in average surface roughness. In these conditions the $R_{\mathrm{a}}$ and $R_{\mathrm{y}}$ records only a short increase at the beginning of the cut, then it starts to decrease evenly below the initial value recorded with $\alpha$-SiAlON cutting tool. This phenomenon is attributed to the stability of temperature of the chips, which was higher leading to the softening of the chip edge sawing action. Opposite facts was observed in condition $\mathrm{A}\left(\mathrm{V}_{\mathrm{c}}=300\right.$ $\mathrm{m} / \mathrm{min}, \mathrm{a}_{\mathrm{p}}=1.0 \mathrm{~mm}$ ) and confirm in Fig. 17 (micrographic), where the lower cutting speed provides minor adhering capability to the lubricant particles on the sliding surfaces required for smearing and lubricating film formation is slowed causing increasing wear rate and possible vibrations that could be attributed to the increased severity of evident surface damage, as see Fig. 20 and Fig 21. The quality of a machined surface is important whilst evaluating the reliability and functional life of the cutting tools.

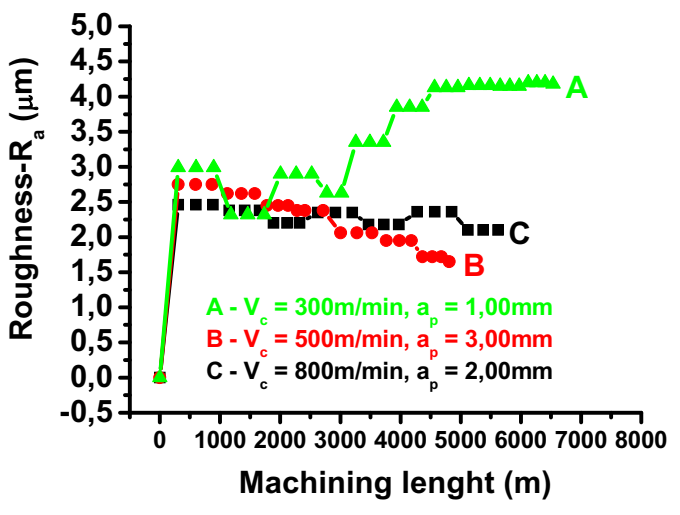

Fig. 20. Surface roughness $\left(R_{a}\right)$ vs. machining length (m).

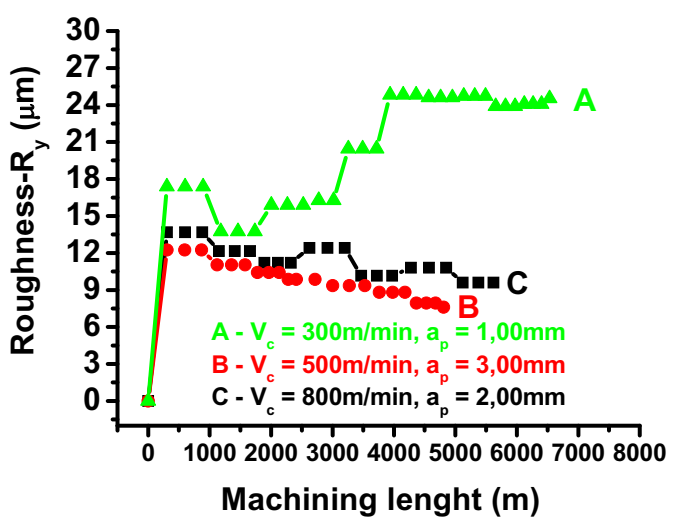

Fig 21. Surface roughness (Ry) vs. machining length (m).

\section{TOOL WEAR ON MACHINING TI-6AL-4V}

In the machining Ti-6Al-4V alloy, the $\alpha$-SiAlON cutting tool are exposed to high mechanical stresses and thermal disturbances resulting in cutting tool wear and short tool life, as see Fig.22 (higher temperature). The most known tool wear type while cutting the Ti-6Al-4V is adhesive wear formed on the rake face due to high thermal combinations, high work hardness and strength of the workpiece and abrasive particles, as see Fig.23. In this figure excessive adhesive wear is seen at higher cutting speed $\left(V_{c}=180 \mathrm{~m} / \mathrm{min}\right)$. Furthermore; flank wear and severe damages are the causes of tool wear. Wear rate of $\alpha$ SiAlON cutting tool at high cutting speed is higher than that at low cutting speeds, conform Fig. 24. In this study we have been observed that at $\alpha$-SiAlON cutting tool is suitable for the machining of Ti-6Al-4V at the cutting speed of $120 \mathrm{~m} / \mathrm{min}$. When increasing the cutting speed from $\mathrm{V}_{\mathrm{c}}=85 \mathrm{~m} / \mathrm{min}$ to $\mathrm{V}_{\mathrm{c}}=120 \mathrm{~m} / \mathrm{min}$ the tool wear value decreased, as see Fig. 24, Fig. 25 and Fig. 26. However a good agreement for result is that in these conditions there are lower reactivity between workpiece/cutting tools. Increasing the cutting speed from $V_{c}=120 \mathrm{~m} / \mathrm{min}$ to 
$\mathrm{V}_{\mathrm{c}}=180 \mathrm{~m} / \mathrm{min}$ observed during machining process the chip material establishes an intimate interface layer with the tool rake face within which continuous shearing phenomenon occurs due to chip flow, the high temperatures prevailing in the cutting zone enhances the chemical reactivity of titanium with the tool material, as see Fig.23. It's caused by transport of tool material into the adherent part of the layer of chip through adhesion-dissolution-diffusion. For all machining conditions used in this paper the adherent layer not protect the tool at the tool-chip interface temperature might reach the levels that increase the chemical reactivity of titanium, as see Fig.22. With increasing temperature, it is possible that the tool may get displaced in radial/axial direction, affecting the dimensional accuracy of the work piece. The observations on the influence of machining temperature on specific cutting speeds have illustrated that the temperature range for machining is $970-1420^{\circ} \mathrm{C}$, as see Fig.22. This situation are important problems reducing tool life due to that the tool having negative and larger clearance angle must be used in order to solve adhesion wear problem. The recommendation for $\alpha$-SiAlON cutting tool for the cutting of Ti-6Al- $4 \mathrm{~V}$ is $\mathrm{V}_{\mathrm{c}}=120 \mathrm{~m} / \mathrm{min}$. Therefore was not suitable for cutting Ti-6Al-4V at high speed.

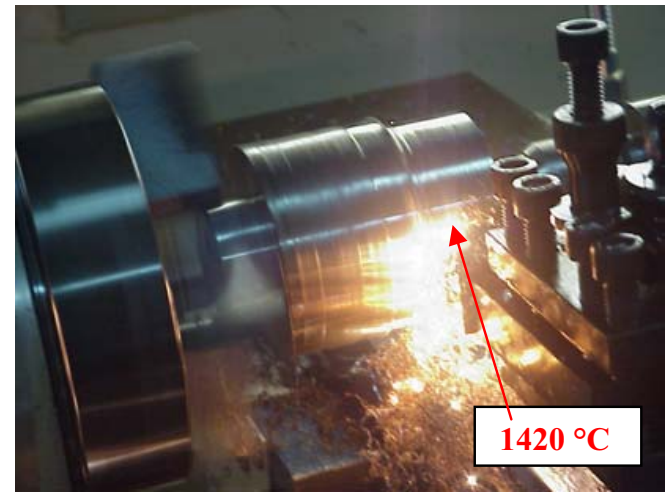

Fig.22. Temperature real during machining (6-4).

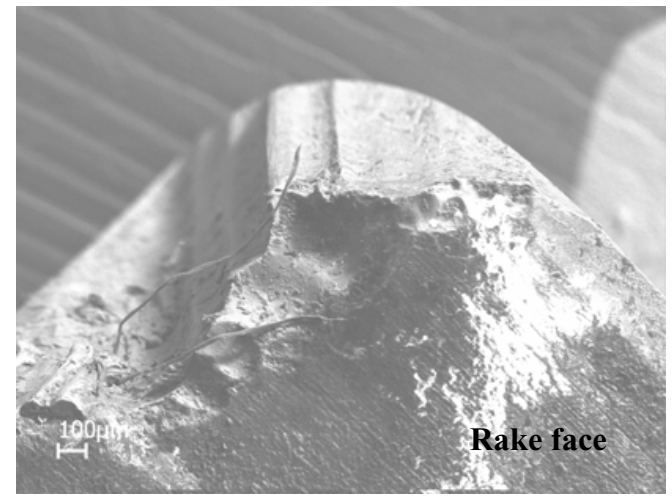

Fig.23. SEM wear profile to $V_{c}=180 \mathrm{~m} / \mathrm{min}, f=0.20 \mathrm{~mm} / \mathrm{rev}$.

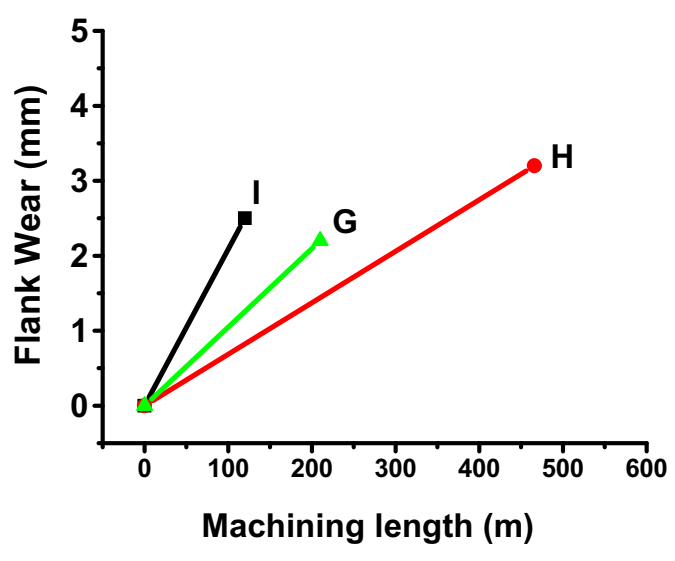

Fig. 24. Flank wear (Vb vs machining length (m).

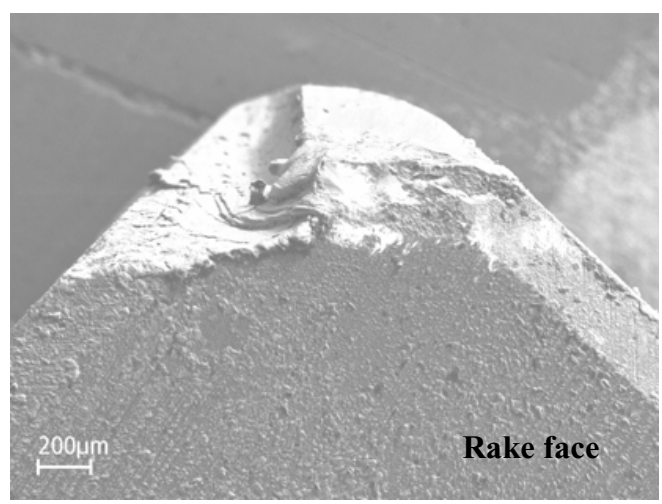

Fig. 25. SEM wear profile to $V_{c}=120 \mathrm{~m} / \mathrm{min}, f=0.05$ $\mathrm{mm} / \mathrm{rev}$.

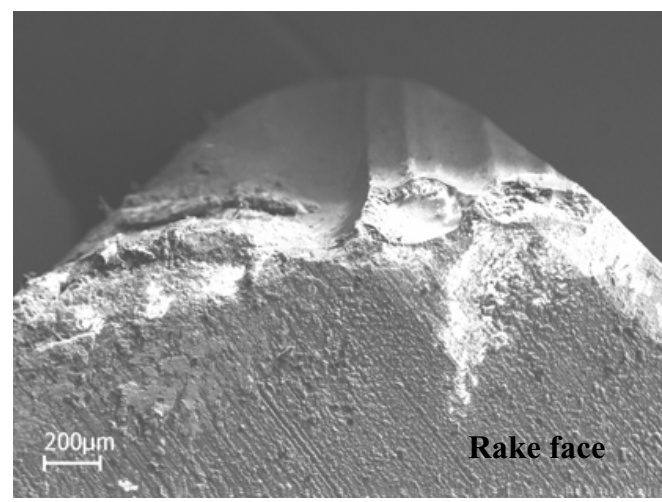

Fig. 26. SEM wear profile to $V_{c}=85 \mathrm{~m} / \mathrm{min}, f=0.10 \mathrm{~mm} / \mathrm{rev}$.

\section{$\begin{array}{lllll}\text { THE } & \mathrm{SI}_{3} \mathrm{~N}_{4} & \text { BASED } & \text { CUTTING } & \text { TOOLS }\end{array}$ GENERALIZATION}

The edge geometry of the laboratory made $\mathrm{Si}_{3} \mathrm{~N}_{4}$ based inserts were expectedly of inferior quality in comparison to that of the commercial ceramics cutting tools. But in spite of this, all the developed composite inserts led to the generation of favourable chip morphology to gray cast iron, compacted graphite iron and unfavourable 
chip morphology to Ti-6Al-4V alloy. This fact is well illustrated by the comparative assessment of the results related to progressive flank wear, temperature and apparent surface roughness on gray cast iron and compacted graphite iron. Cutting tools surface quality is thus unambiguously considered to result in not enough resistance to chipping and micro-fracturing of the cutting edges of the inserts. The improved performances of these cutting tools are attributed to the optimum combination of hardness, fracture toughness and thermal conductivity. Thus, it can be inferred that if $\mathrm{Si}_{3} \mathrm{~N}_{4}$ based inserts are using with appropriate machining parameters provide further improved performance and may even outperform the some type inserts. The enhanced cost due to ceramics cutting tools can be expected to be compensated by the simple and inexpensive route of materials manufacturing. On an overview, this report demonstrates the development of advanced ceramic cutting tools on the major basis of the study on the progressive flank wear, supplemented by several necessary engineering considerations.

\section{CONCLUSIONS}

In the dry machining experiments, the tools have been explored in different conditions to turning gray cast iron, compacted graphite iron and Ti-6Al-4V. This was done with the intention of study the performance of $\alpha$-SiAlON cutting tool development in Brazil. Based on the results obtained, the following conclusions can be drawn:

\section{COMPACTED GRAPHITE IRON}

The test results show that acceptable tool life can be achieved when machining compacted graphite iron (CGI) with $\alpha$-SiAlON cutting tool using cutting speed of $300 \mathrm{~m} \mathrm{~min}^{-1}$ and cut depth of $1.00 \mathrm{~mm}$, which gave better stability, promote lower friction coefficient.

Increase in cutting speed to $V_{c}=300 \mathrm{~m} \mathrm{~min}^{-1}$ and $a_{p}=$ $1.00 \mathrm{~mm}$ promoted the interaction of process energies, including temperature, which in turn accelerates various wear mechanisms, resulting in more severe tool wear and reduced tool life.

\section{GRAY CAST IRON}

The performance of the $\alpha$-SiAlON cutting tool on grey cast iron machining has been promising with important value of cut length, low roughness and flank wear for different cutting speeds. However, at medium cutting speed $(500 \mathrm{~m} / \mathrm{min})$, it significantly reduced the tool flank wear and increased the tool life. This study also brought out some interesting and useful observations for future researches in development, manufacture and machining test with $\alpha$-SiAlON cutting tools. The results obtained are encouraging and dry machining can be a good environment friendly option for manufactures process.

\section{Ti-6Al-4V}

The investigation of the $\alpha$-SiAlON cutting tool shows that the best machining condition was obtained at $\mathrm{Vc}=120$ $\mathrm{m} / \mathrm{min}$. Through the analyses of studies can be concluded that there are chemical affinity from two materials. Some elements of the Ti-6Al-4V alloy diffuse in the inserts.

\section{ACKNOWLEDGEMENTS}

The authors would like to express their gratitude to CAPES and FAPESP.

\section{REFERENCES}

[1] E.O. Ezugwu, Key improvements in the machining of difficult-to-cut aerospace superalloys, International Journal of Machine Tools and Manufacture, V. 45, 2005, pp.13531367.

[2] P.S. Sreejith and B.K.A. Ngoi, Dry machining: machining of the future, Journal of Materials Processing Technology 101 (2000), pp. 287-291.

[3] G. Brandt, Ceramic cutting tools, state of the art and development trends, Materials Technology 14 (1999) (1), pp. 17-22.

[4] Ai Xing, Li Zhaoqian and Deng Jianxin, Development and perspective of advanced ceramic cutting tool materials, Engineering Materials 108 (1995), pp. 53-66.

[5]E. Uhlmann, U. Lachmund and M. Brücher, Wear behavior of HFCVD-diamond coated carbide and ceramic tools, Surface and Coatings Technology, 131, (2000), pp. 395-399.

[6] http://www.freedoniagroup.com/Advanced Ceramics.html, 07/03/2008.

[7] G.W. Stachowiak and G.B. Stachowiak, Wear behaviour of ceramic cutting tools. Key Eng. Mater. 96 (1994), pp. 137-164.

[8] H. Schulz, J. Dörr, I.J. Rass, M. Schulze, T. Leyendecker and G. Erkens, Performance of oxide PVDcoatings in dry cutting operations. Surface and Coatings Technology 146-147 (2001), pp. 480-485.

[9] M. Lahres, O. Doerfel and R. Neumüller, Applicability of different hard coatings in dry machining an austenitic steel. Surface and Coatings Technology 120-121 (1999), pp. 687-691.

[10] E. Brinksmeier, A. Walter, R. Janssen and P. Diersen, Aspects of cooling lubrication reduction in machining advanced materials. Proceedings of the Institution of Mechanical Engineers 213 Part B (1999), pp. 769-778.

[11] A.S. Varadarajan, P.K. Philip and B. Ramamoorthy, Investigations on hard turning with minimal cutting fluid application (HTMF) and its comparison with dry and wet turning. International Journal of Machine Tools and Manufacture 42 (2002), pp. 193-200.

[12] J.V.C.Souza, et al., $\alpha$-SiAlONs Cutting tool Development, characterization and Application in Machining of Compacted Cast Iron, 7 th International 
Conference on Advanced Manufacturing Systems and Technology, Udine (Italy), June, 2005.

[13] Ductile Iron Data For Desing Engineer, Ductile Iron Society (DIS), 2001.

[14] E.M. Trent, Metal Cutting, Tanner Ltd., London (1984).

[15] The Iron Casting Handbook, Iron Casting Society, Inc., 1981.

[16] Machining Data Handbook, 3rd ed., Metcut Research Associates, Inc., Cincinnati, OH, 1980.

[17] Machining Ductile Irons, International Nickel Co. Inc., New York, 2001.

[18] U. Reuter, H. Schulz and M. McDonald, Compact and bijou - the problems associated with CGI can be overcome, Engine Technol Int 4 (1999), pp. 58-60.

[19] M. McDonald and M. Dawson, Compacted graphite iron and current trends in engine design, Engine Technol Int (1999).

[20] President Titanium Machining and Technical Data, President Titanium, Hanson (1999).

[21] S. Dawson, Hollinger L, Smiles P., The mechanical and physical properties of compacted graphite iron, 1998, company brochure, SinterCast Ltd.

[22] D.M. Stefanescu, R. Hummer and E. Nechtelberger, Compacted Graphite Irons (ninth ed.), Metals Handbook vol. 15, ASM International (1992) pp. 667-677, 2nd printing.

[23] J. V. C. Souza, S. J. Crnkovic, C. A. Kelly, M. R. V. Moreira, M. V. Ribeiro, O. M. M. Silva, Behavior of the
Silicon Nitride Cutting Tool During Ti-6Al-4V Machining. In: Fifth International Conference on High Speed Machining, 2006, Metz.

[24] C. Doré, J. H. Bagetti, L. Boehs, W. L. Guesser and A. H. A. Bressiani, Avaliação do Desempenho de Ferramentas de Cerâmica $\mathrm{Al}_{2} \mathrm{O}_{3}+\mathrm{Y}_{2} \mathrm{O}_{3}+\mathrm{NbC}$ na Usinagemde Ferro Fundido Vermicular, In Anais COBEF 2007.

[25] J.V. C. Souza; E. A Cunha; M. R. V. Moreira; G. V. Martins; E. A.Raymundo, C. A.Kelly, Usinagem de Ferro Fundido Vermicular com Pastilhas Cerâmicas a Base de Nitreto de Silício. Máquinas e Metais, v. 470, p. 140-155, 2005.

[26] C. Santos, K. Strecker, S. Ribeiro, J.V.C. Souza, O.M.M. Silva and C.R.M. Silva, Mater. Lett. 58 (2004), pp. 1794-1796.

[27] F.L. Riley, Silicon nitride and related materials. J. Am. Ceram. Soc. 832 (2000), pp. 245-265.

[28] K. Strecker, R. Gonzaga, S. Ribeiro and M.J. Hoffmann, Substitution by a rare earth oxide mixtures as sintering additive of $\mathrm{Si}_{3} \mathrm{~N}_{4}$ ceramics. Mater. Lett. 45 (2000), pp. 39-42.

[29] S. Ribeiro, K. Strecker, F. Vernilli, Jr., Estudo comparativo da oxidação do nitreto de silício sinterizado com óxidos de ítrio e de terras raras, in: L. Guerra Rosa (Ed.), Encontro Nacional da Sociedade Portuguesa de Materiais 8, Materiais'97, vol. 2, Marinha Grande, Portugal, Anais, Sociedade Portuguesa de Materiais, Aveiro, 1997, pp. 133-141. 
The Engineering Meetings Board has approved this paper for publication. It has successfully completed SAE's peer review process under the supervision of the session organizer. This process requires a minimum of three (3) reviews by industry experts.

All rights reserved. No part of this publication may be reproduced, stored in a retrieval system, or transmitted, in any form or by any means, electronic, mechanical, photocopying, recording, or otherwise, without the prior written permission of SAE.

For permission and licensing requests contact:

SAE Permissions
400 Commonwealth Drive
Warrendale, PA 15096-0001-USA
Email: permissions@ @ sae.org
Tel: $\quad 724-772-4028$
Fax: $\quad 724-776-3036$

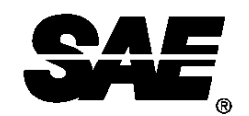

Global Mobility Database ${ }^{\circledast}$

All SAE papers, standards, and selected books are abstracted and indexed in the Global Mobility Database.

For multiple print copies contact:

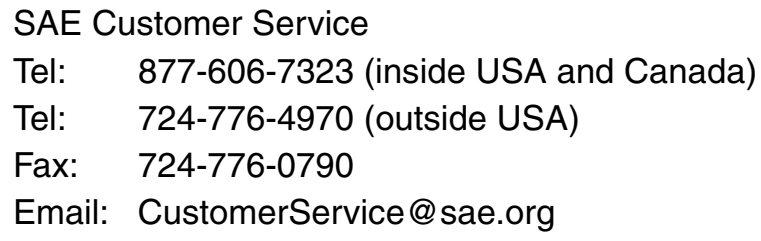

\section{ISSN 0148-7191}

\section{Copyright $\odot 2008$ SAE International}

Positions and opinions advanced in this paper are those of the author(s) and not necessarily those of SAE. The author is solely responsible for the content of the paper. A process is available by which discussions will be printed with the paper if it is published in SAE Transactions.

Persons wishing to submit papers to be considered for presentation or publication by SAE should send the manuscript or a 300 word abstract to Secretary, Engineering Meetings Board, SAE. 